\title{
Tax Evasion, Tax Avoidance and The Influence of Special Interest Groups: Taxation in Iceland from 1930 to the Present ${ }^{* *}$
}

DOI 10.1515/ntaxj-2015-0006

Received Aug 05, 2015; accepted Oct 16, 2015

\begin{abstract}
This paper focuses on tax evasion and tax avoidance in Iceland, and on how special interest groups have shaped the taxation system to serve their own ends. The period covered is from 1930, when the present Icelandic system of power was established, to the present.

Tax evasion is sometimes an intended, and other times an unintended response to taxation. Willful tax evasion is more likely to occur if consensus regarding fairness and equality of the tax-code is lacking. Tax evasion is an integral part of the "underground economy", or more formally, the Non-Observed Economy (NOE). Measuring the size and scope of the NOE in general, and tax evasion in particular, is a difficult task. We compare results from three methods for estimating the size of the Gross Domestic Product (GDP): the production approach, the expenditure approach, and the income approach. The results of applying these three methods should, in principle, be identical, but they are not. We use the difference, guided by historical facts and anecdotes, to give an idea of the magnitude of tax evasion during the $20^{\text {th }}$ century.

We suggest that the construction of the tax system to serve special interest groups may have disrupted the social, judicial, political and economic balance of the Icelandic "project".
\end{abstract}

Keywords: Tax Evasion; Tax Avoidance; Icelandic Tax System; Governance

JEL-codes: H2, H3, H5, H6, N1, N2

There is no part of the administration of government that requires extensive information and a thorough knowledge of the principles of political economy, so much as the business of taxation. The man who understands those principles best will be least likely to resort to oppressive expedients, or sacrifice any particular class of citizens to the procurement of revenue. It might be demonstrated that the most productive system of finance will always be the least burdensome.

Alexander Hamilton, Federalist, No. 351788.

\section{Introduction}

The purpose of a country's taxation regime is to facilitate the funding of useful projects, to redistribute rents, and to fund social insurance schemes. Taxes can be collected in many different ways. A particular method may be less burdensome for a given group than another method. However, taxes affect economic behavior and transfer resources from the taxpayer to someone else. Hence, vested interests will try to dictate the principles used for funding and redistribution embedded in the tax-code.

Taxation policy is shaped by political institutions that are, unfortunately, subject to corruption. Corruption is a complex phenomenon that all governmental structures, private or public, have to deal with. The objectives of bureaucrats and politicians are not necessarily in harmony with those of the general public. Research by OECD shows that corruption is harmful to economic growth; it increases inequality and poverty, and it affects the allocation of public spending and publicly financed infrastructure (OECD (2012)).

In developing countries, where the distinction between the private and public sphere is often unclear, cor-

\footnotetext{
$\star \star$ We would like to thank two unknown readers for their remarks. We would also like to thank Mikael M. Karlsson, Professor at the University of Iceland, for helpful criticisms on various points in need of improvement, and Ólöf Pétursdóttir for reading through the whole document. The authors themselves bear full responsability for the contents.
}

\begin{abstract}
Johannes Karlsson: Master of Science in Economics from the Department of Economics, University of Iceland. The present paper is partially based on Karlssons' qualifying essay, which he wrote under the supervision of Professor Matthiasson

^Corresponding Author: Thorolfur Matthiasson: Professor of Economics, University of Iceland; Email: totimatt@hi.is
\end{abstract}


ruption has been defined as: "abuse of entrusted authority for illicit gain" (NORAD (2009)). For a developed country, such as Iceland, this definition is too broad. Therefore, we will use the definition of the World Bank (2006) and the UNDP (2004) for corruption: "the abuse of public office for private gain". This sort of corruption includes bribery, fraud, nepotism, falsification of records, and illicit campaign contributions. Corruption and governance failures also include behaviors (e.g. lobbying) that may or may not be legal, but are driven by the narrow and self-serving interests of powerful elites, in particular, policy-makers (bureaucrats and politicians) and special interest groups (SIG). Sources of revenue are central to shaping elite incentives and strategies. For example, it makes a difference whether or not the elite consists of employees, i.e. bureaucrats, who 'earn' their pay, or whether their revenues are 'unearned', for instance rents arising from high-value natural resources, as in the case of the owners of fishery quotas in Iceland. For both groups, the incentive is to increase their income and power by increasing spending and the control of resources, or else by relying on specific institutional details of budgeting, taxation and the legislative process.

This paper focuses on tax evasion and tax avoidance in Iceland, and on the way special interest groups have used lobbying and other avenues of influence to shape the taxation system to serve their own ends. The period covered is from 1930, when the present Icelandic system of power was formed, to the present. Special interest groups transmit the policy preferences of their constituents to elected officials, while political parties are focused on maximizing their representation in forums of formal power (Parliaments, local governments). These competing goals have important implications for the relationship between SIGs and the political parties (Brunell (2005)).

The ethics and morality of lobbying are double-edged, sometimes normal and natural, but often not; and therefore, in most countries, lobbying predicated upon campaign contributions and other such 'inducements', is regulated by law. In Iceland, campaign-contribution legislation did not exist until after the crisis of 2008 and, according to international observers (GRECO (2013)), both the legislation and the monitoring system in Iceland are in need of improvement.

This paper is organized as follows. In the next section, we seek to estimate the magnitude of tax evasion in Iceland since 1930. In section 3, we describe the influence of clientelism on the structure of the taxation administration in Iceland. In the last section, we present our general conclusions.

\section{Magnitude of tax evasion in Iceland, 1930 to present}

\subsection{Introduction}

The term Non-Observed Economy (NOE) refers to all gainful activities not officially declared, whether payments are made or not. These include: underground production, illegal production, informal sector production and production of household goods for one's own final use. Tax evasion is an integral part of the NOE, whether the purpose of non-declaration is to evade taxes or to an illegal activity from the tax authorities. Hence, measuring the size of the NOE in general, and of tax evasion in particular, is difficult and prone to errors.

Three different methods have been used to assess the Gross Domestic Product (GDP): the production approach, the expenditure approach, and the income approach (UN (1993)). The results of applying these three methods should ideally be identical, yet they are not, for a variety of reasons. The first estimates of the Icelandic GDP, produced in 1953, were based on the expenditure approach. Estimates based on the income approach, utilizing tax-return data, were not published until 1964. The income approach indicated significantly lower GDP than the expenditure approach, see Figure 1. Early researchers suggested that the difference could be attributed, at least partly, to tax evasion. It is now recognized that the discrepancy is caused by many factors, in addition to tax evasion, tax avoidance, and corruption; for instance, mismatches where a buyer dates a transaction differently from a seller, errors in registration, definitional misunderstandings, difficulties in evaluation caused by inflation, etc., (see Box 1).

\subsection{Up to WWII}

Icelandic GDP for the period from 1930 to 1940 has been calculated retroactively, using both the expenditure and the income approach. Producing fresh estimates for GDP for years long gone is more prone to mistakes than estimating GDP for the current or a very recent period. But the difference of 13 to 30 percent during the period is substantial, see Figure 1.

However, the income approach might render figures that are too low, since it has been shown that the municipality income tax base was much higher than the central income tax base. The estimate of the GDP from the income side was based on the latter. Yet the difference between the 


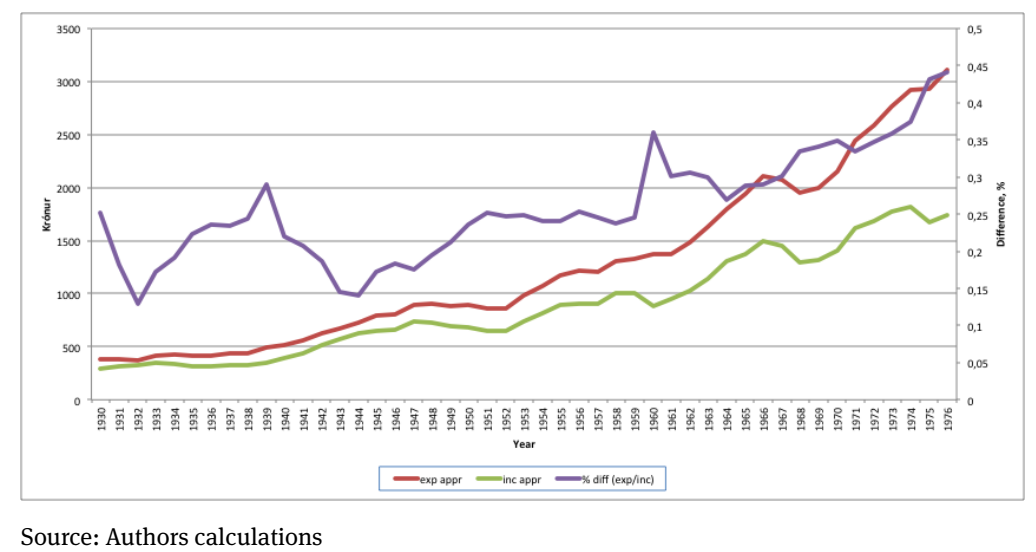

Figure 1: The percentage difference (right hand scale) between GPD estimated by the Expenditure Approach and the Income Approach 1930-1976.

\section{BOX 1}

Until 1931, there were no special laws or regulations ruling the Central Government Accounts, and the records depended rather on the whims of the Finance Minister than on any accounting system. Certain tax collectors-the District commissioners-freely dispensed accrued taxes without prior authorization from the Treasury or Parliament (Atvinnumálaráðuneytið (1931)). In addition, the Government did not present the accounts to the Parliament until two to four years after the end of the respective financial year, when the interest in that particular year's activities and accounts was naturally somewhat reduced; and by that time any disapproval that there might be concerning excess expenditures would not be to much avail anyway. According to the Parliament, the tax evasion of craftsmen was about 10 percent in the 1930s. Importers used false invoices to show that purchase prices were up to 10 times higher than they actually were, and this affected the whole community. In 1936, the oil distribution companies in Iceland, British Petroleum in Iceland (BP) and the Shell Company in Iceland, were caught red-handed in counterfeiting invoices and price-fixing in order to increase their profits by millions of krónur. The General director of BP, an MP for the Social Democrats and the Chairman of the State Internal Revenue Board, and the Chairman of the Shell Company was a former Finance and Justice Minister for the Independence Party. No action was taken to correct the situation, however, and the oil companies kept up their collusion in one way or another for many years. Interestingly, the story seems to repeat itself: in the 1990s, the three main oil companies in Iceland were charged with price-fixing after a very thorough investigation by the Competiton Authority. Everything was done to delay the case. The oil companies had direct access to all political parties. For example, the Minister of Justice for the Independence Party was the wife of the General Director of the Shell Company in Iceland. After the case attracted the attention of the newspapers, the Minister of Justice became the Speaker of the Parliament, while the director of the institution that initiated the case lost his job. In Iceland, the fishing industry is the basis of elite power. Therefore, it is not surprising that bribes, counterfeit invoices, price-fixing and transfer-pricing are frequent in that sector. The main elite family in Iceland during the early $20^{\text {th }}$ century was the Thors family, and the head of that family was the leader of the Independence Party 1934-1961. The family based its power on two fishing companies: Kveldúlfur and Icelandic Seafood (SÍF). In 1949, Icelandic Seafood was caught red-handed committing all of the above-mentioned reprehensible acts (bribery, counterfeiting invoices, price-fixing and transfer-pricing) in Italy and Greece. An employee of the Federation of Icelandic Fishing Vessel Owners, LIIU, in London, was the one who unveiled these activities. He examined the case and, according to him, the company had obtained millions of kr'onur through fraud, starting in 1932 with the establishment of Icelandic Seafood. The General Director of Icelandic Seafood was in the Thors family, the brother of the Minister of Fisheries, who had granted the company a monopoly to export bacalao from Iceland. However, that monopoly license was revoked when the coalition of the Independence Party and the Progressive Party was defeated in the late 1950s, and a cleanup process was started. The Independence Party and Progressive Party have been labeled war profiteers for their involvement with the US Army in the WWII, which actually concerned the division of the war profits. 
results from each of the two methods is so considerable that it pretty clearly points to considerable non-observed activity. Both anecdotes and more solid evidence point to significant tax evasion involving the oil companies, the fishing industry, and the importers, see Box 1.

\subsection{Post-WWII Years}

The post-WWII years up to 1960 are the years of independence, of rapid spending of funds accumulated during the war, of multiple currency rates and of the rigid control of imports. Icelandic GDP, as measured by the expenditure approach on the one hand, and as calculated on basis of the income approach on the other, differs by 14 to 35 per cent between 1940 and 1960, see Figure 1.

Restoring order in economic affairs after a war is a considerable task, even if the country in question was occupied by "friendly forces" and avoided becoming a battleground or a stage for sabotage. The number of foreign servicemen in Iceland went as high as 50.000 against a population of 38.000 in the capital (and 120.000 overall) (University of Iceland (2010)). New markets for services opened, formerly worthless assets attracted a price. Not all income resulting from this surge of activities was reported in tax returns. Based on practices established after WWII in Germany, Norway and Denmark, Icelandic tax authorities mounted a property investigation in 1948. Tax evasion was defined by comparing change of assets owned between the end of 1947 and the end of the year 1939, deducting saving and asset sales during the period.

Special tax returns were published for this purpose, and new currency was issued at the same time. People stood in lines in front of the currency-exchange stations all around the country to change their old currency for new; but the results in terms of recovery were small, and no one was charged with tax fraud. One reason was the fact that the administration was weak, and the Minister of Finance declared that there was no need to punish tax evaders, as they were only fending for themselves. Lack of results in tax cases does not mean that a tax inspector is useless: From 1942 to 1950, there are indications that the Independence Party was able to use the special tax investigation office to keep track of political opponents (Borgarskjalasafn Reykjavíkur (1940)) ${ }^{1}$. Furthermore, the governance of the

1 The Minister for Foreign Affairs (who was also the Minister of Justice), went to the American Embassy in Reykjavik in the 1940s to get the FBI to investigate the tax affairs of Halldór Laxness, Iceland's Nobel Prize winning author, in order to attack him. Laxness had paid all municipal tax system was linked directly to the political system during the period 1872-1972.

\subsection{From 1960 to 1980}

Icelandic GDP, as measured by the expenditure approach, and as calculated on basis of the income approach, differed by 25 to 45\% between 1960 and 1976 (See Figure 1). The period began with an overhaul of the economic policy, a system of multiple currency rates for the ISK, while the system of export levies and import subsidies was abandoned. Attempts were made to reduce the power of unions and free up trade in currency and the banking sector (Gunnarsson (1988)). Notable also were attempts to reform the tax system by introducing a sales tax, as reported below.

In the 1950s, tax evasion was estimated to amount to around 25 percent of the total revenue of the State by Ólafur Björnsson, Professor of Economics at the University of Iceland (OEEC (1958)); but after economic reforms in 1960, especially after the introduction of the sales tax, indicators show an increase in estimated tax evasion, (see Figure 1), where the difference between GDP estimationmethods goes from $24.6 \%$ in 1959 to $35.9 \%$ in 1960 and to $26.9 \%$ in 1964 . The decline observed between 1960 and 1964 may have been caused by tax-reforms instituted by the government of the Independence Party and the Social Democrats in 1960. Inflation had pushed low wage earners into higher and higher tax brackets. To counter tax-payer uneasiness the government introduced indexation of the brackets.

In the 1970s, the IMF was concerned that tax fraud was a hindrance to economic growth in Iceland (IMF (1972)). The tax legislation for companies was not aligned to that of other countries until Iceland joined EFTA in 1970. According to the IMF, most of the big companies had by then stopped fraudulent behavior (see Figure 2), but sales tax evasion had increased (see Figure 3), and the legislation applicable to individuals was still a mess, although some MPs with labor union ties had started inquiring about grants and campaign contributions to the Independence Party.

In 1976, there were strong protests against tax fraud, and some improvements were made in the tax system and in tax administration; inflation accounting was intro-

\footnotetext{
his taxes on time, both in America and in Iceland. All matters concerning income and taxes were the responsibility of the Minister of Finance, except those under the special tax investigation office, that were the responsibility of Minister of Justice (Guðmundsson (2004, pp. 539-542)).
} 


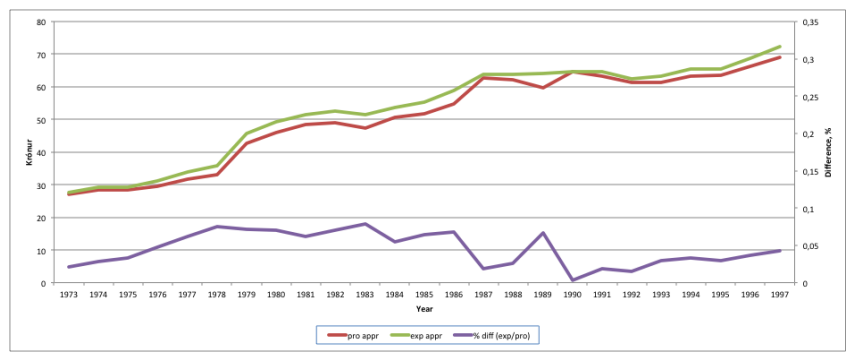

Source: Authors calculations

Figure 2: The Percentage difference (right hand scale) between GDP estimated using the Expenditure Approach and the Income Approach 1973-1997.

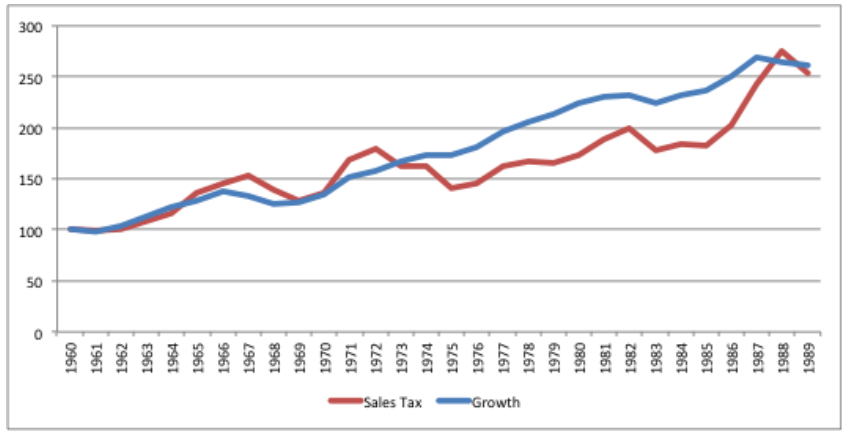

Figure 3: Collected sales tax and growth of GDP per person 1960$1989,1960=100$.

duced, and the Tax Penalty Committee and State Internal Revenue Board were merged.

\subsection{Special Interest Groups and the Road to the Crisis}

The main special interest groups Iceland were the Federation of Icelandic Fishing Vessel Owners (LÍU, now included in Fisheries Iceland, SFS $)^{2}$ and the co-operative movement

2 At the end of the 1930s, the Independence Party and the Progressive Party made a coalition deal in response to the tax policy of the first leftist government in Iceland. The coalition was formed by party leaders, who at the time were both members of the Board of Directors of the Landsbanki Íslands (Bjarnason (1943); Valdimarsson (1984)). These two gentlemen were both MPs and Ministers over a long period and were also in charge of the two largest Special Interest Groups in Iceland. At the beginning of 1939, the fishing vessel owners and the co-operative movement joined forces in the Federation of Icelandic Fishing Vessel Owners (Landsambands íslenskra útvegsmanna, LÍU, now included in Fisheries Iceland, Samtök fyrirtækja i sjávarfyrirtæki, SFS) under the leadership of the General Director of the co-operative movement (Sís), and an MP who was one of the founders of the Independence Party in 1929: a member of the Board of Directors of Landsbanki Îslands 1938-1944, a long-time spokesman formerly organized in the now defunct SÍS now included in Samskip. ${ }^{3}$ LÍU has always been the main supporter of the Independence Party, while SÍS was from the outset the main supporter of the Progressive Party. Through the privatization of the banks in 2003, these two groups, and thereby the two political parties, split the banking system between them, ${ }^{4}$ see Box 2 (Thorhallsson $(2008,2010)$; Thorhallsson \& Kattel (2012)). These groups are empowered by a faulty voting system ${ }^{5}$. The most important point

for the fishing vessel owners, and Minister of Fisheries, Industries and Finance for the Independence Party 1947-1950 (Ragnarsson (1999)). 3 Samband íslenskra samvinnufélaga (Sís) has not been active economically since 1993, (Wikipedia (2015b)) The shipping arm of Sís, Samskip, has continued operation, ownership has shifted but strong ties have been maintained between owners of Samskip and the Progressive Party. The chairman of the Board of Directors of Samskip, and its main owner, gave the Progressive Party a house, the center for the party in Reykjavík, in December 2002, just before the privatization of the banks in 2003, and the chairman was the leader of the group that bought Kaupthing Bank, (DV (2012)). In 2015, he was sentenced to four and a half year imprisonment for market manipulation; see also Box 2.

4 According to a report by the Competion Authority in the 1995 (see also Boxes 1 and 2 and the two footnotes above) there were two main Special Interest Groups in Iceland: the Octopus and the Squid. In the former, there were 54 companies, where LÍU, Eimskip, the leading commercial shipping company in Iceland, Landsbanki Íslands and Icelandair were the main players, while in the latter, companies related to SíS or Samskip are prominent, including Búnaðarbanki Îslands, later Kaupthing Bank. In Iceland, the pension funds are outside the tax system, and these funds are the main Icelandic investors. According to the same report, the board members of these Special Interest Groups, or persons related to them, manage the investments of the pension funds, and they direct all the pension funds' investments to their own companies (Alpýðublaðið (1995); Friðriksson (1995)).

5 "Government by the people" has never been a recognized political principle in Iceland, just as the rule "one person, one vote" has never been in force. Women got the right to vote in 1915, the same applied to farmhands. However, according to the tax law, married women were not independent taxpayers until 1979, and the head of the family, or the farmer, paid the taxes for the farm hands until 1934, and in practice even longer. Until 1934, the right to vote was restricted to those eligible to pay taxes. Voters in urban areas have always had fewer representatives per 1000 voters than voters in rural areas (the difference could be 1:5). Contemporary economic theories are based on the assumption that the rule "one person, one vote" applies. In the case of public expenditures, it means half of the voters would want more spending, and half less. In Iceland, this basic rule has never been applied. Those parties that have profited from the election system are the Progressive Party and the Independence Party (Karlsson (2014); Stiglitz (2000)). 


\section{BOX 2}

\begin{tabular}{|c|c|c|c|c|c|c|c|c|c|}
\hline & 1997 & 1998 & 1999 & 2000 & 2001 & 2002 & $2003^{\star}$ & 2004 & 2005 \\
\hline $\begin{array}{l}\text { 1. Disposable income of the house- } \\
\text { hold sector }\end{array}$ & 255.330 & 281.840 & 307.738 & 349.478 & 365.340 & 402.034 & 422.481 & 467.750 & 529.720 \\
\hline 2. Households' final consumption & 295.516 & 330.262 & 365.912 & 400.154 & 418.190 & 430.988 & 463.308 & 511.556 & 588.633 \\
\hline 3. Net savings & -40.186 & -48.422 & -58.174 & -50.675 & -52.850 & -28.954 & -40.827 & -43.806 & -58.913 \\
\hline $\begin{array}{l}\text { 4. Depreciation of dwellings and indi- } \\
\text { vidual buisness activities }\end{array}$ & 17.435 & 19.386 & 22.639 & 25.563 & 27.512 & 28.377 & 31.409 & 36.745 & 46.929 \\
\hline 5. Gross savings $(5 .=3 .+4)$. & -22.751 & -29.036 & -35.535 & -25.112 & -25.338 & -577 & -9.418 & -7.061 & -11.984 \\
\hline 6. Residential construction & 20.678 & 21.573 & 22.217 & 25.886 & 31.714 & 39.354 & 42.483 & 50.626 & 58.466 \\
\hline $\begin{array}{l}\text { 7. Gross fixed capital formation in un- } \\
\text { incorporated enterprises }\end{array}$ & 6.565 & 7.417 & 10.956 & 9.317 & 9.028 & 6.226 & 6.641 & 7.752 & 12.650 \\
\hline $\begin{array}{l}\text { 8. Net lending }(+) / \text { Net borrowing }(-) \\
(8 .=5 .-6 .-7 .)\end{array}$ & -49.993 & -58.026 & -68.708 & -60.315 & -66.080 & -46.157 & -58.542 & -65.439 & -83.099 \\
\hline 8.1. Incurrence of liabilities & 43.716 & 65.312 & 78.147 & 104.170 & 76.553 & 98.263 & 48.607 & 114.889 & 244.556 \\
\hline 8.1.1. Net lending to households & 34.845 & 58.265 & 62.172 & 92.633 & 64.645 & 91.147 & 39.698 & 95.675 & 197.628 \\
\hline $\begin{array}{l}\text { 8.1.2. The share of unincorp. en- } \\
\text { terpr. in lending to ind. }\end{array}$ & 8.871 & 7.047 & 15.974 & 11.537 & 11.908 & 7.116 & 8.908 & 19.214 & 46.928 \\
\hline 8.2. Acquisition of financial assets & 24.653 & 39.270 & 41.863 & 34.958 & 27.561 & 35.620 & 117.304 & 74.883 & 85.625 \\
\hline $\begin{array}{l}\text { 8.2.1. Increase in households } \\
\text { deposits }\end{array}$ & 6.832 & 13.818 & 16.823 & 18.123 & 19.246 & 35.853 & 57.183 & 28.826 & 53.725 \\
\hline $\begin{array}{l}\text { 8.2.2. The share of unincorp. } \\
\text { enterpr. in deposits of } \\
\text { ind. }\end{array}$ & 569 & 617 & 1.254 & 751 & 1.055 & 1.042 & 1.246 & 1.120 & 1.529 \\
\hline 8.2.3. Increase in securities & 9.273 & 20.718 & 20.582 & 10.903 & 8.032 & 87 & 59.430 & 48.422 & 22.504 \\
\hline 8.2.4. Increase in shares & 7.978 & 4.116 & 3.204 & 5.181 & -772 & -1.362 & -555 & -3.486 & 7.868 \\
\hline 9. Discrepancy in financial balance & -30.930 & -31.984 & -32.425 & 8.898 & -17.088 & 16.486 & -127.239 & -25.433 & 75.831 \\
\hline
\end{tabular}

(9. $=8 .+8.1 .-8.2$.

Source: Statistics Iceland (2007); Central Bank of Iceland (2004); Tómasson (2009, 2013); Hjartarson (2010); Porláksson (2008); Financial Times: http: //search.proquest.com/docview/248630001; Johnsen (2014) and Karlsson (2010).

According to the Financial Times, UK London, April 7, 1998, the Icelandic PM for the Independence Party, Mr. Oddsson, had ordered a study into how the country could emulate Luxembourg and Switzerland as a "safe haven" for depositors who value secrecy. “The plan for the Offshore Trading Center came into force with Act No 31 of 1999. Moreover, in 2005, Halldór Ásgrımsson, the leader of the Progressive Party and PM at that point, appointed Sigurður Einarsson, CEO of Kaupthing Bank, head of a committee with the task to change Iceland into a tax haven especially designed for Icelandic expatriates living in the UK and Luxembourg. Sigurður Einarsson was sentenced to a 5 year prison for market manipulation in the summer of 2015.

In 2003, there was excessive unexplained financing of the Icelandic economy, amounting to 127 billion ISK (after the adjustments of Statistics Iceland), roughly the equivalent of 10 per cent of the GDP. According to the CBI, this is mainly due to changes in methodology, but according to Statistic Iceland, this hypothesis does not hold. The greatest difference appears in items 8.1.1, and 8.2.1. To put it bluntly, this reeks of money laundering, tax evasion or both, yet it has not been researched. There is a direct correlation between capital assets of so-called foreign investors in Iceland (pension funds, Icelandic Fishing Vessel Owners, and the banks) and the assets of Icelanders abroad. These tansaction from tax havens increased enormously in 2001 and have been estimated to be upto a 100 per cent of the GDP per year and no taxes were paid.

In 2003, the Icelandic banks (Glitnir, Kaupthing Bank and Landsbanki Îslands) took several huge loans in foreign countries. It was known from the onset that they and in 2004, the Icelandic banks started to finance the brand-new private branch of housing loans market in Iceland.

In 2003, the coalition government of the Independence Party and the Progressive Party privatized the banks, delivering them into the hands of their friends, although they never paid for them, and therein lies the root of the financial crisis of 2008. The Icelandic businessmen who bought Landsbanki, Björgólfur Guðmundsson, his son Björgólfur Thor and Magnús Porteinsson) had had several breweries in Saint Petersburg, Russia. These ventures in Russia did raise suspicion at the time, and many serious newspapers wondered where this people got their funds.

It is remarkable that in early 2009, Boris Berezovsky a Russian business oligarch, had this to say in Sky News, http://www.youtube.com/watch?v=JI3NqnjzUFw: "And you remember three months ago, Russian government decreed that they would help Iceland. And Russian is so strong that they are able to help even a member of NATO. And the trick is very simple because Russian top-level bureaucrats like Putin, like others - and the oligarchs together they create a system how to operate in the West, how to use this fantastic money to buy assets and so on. And they find a very clever solution. The took a country and bought the country, 
which is a member of NATO and not a member of EU, because regulations are different. They put a lot of money, dirty money into it. ..”

Gunnar Tómasson, a respected Icelandic economist, also pointed out in his blog in 2014, that the increase of interest rates paid by the Icelandic state, from 1/25 of the GDP in 2004 to $1 / 3$ in 2008, amounts to a drastic draining of society. Gunnar remarks: "It is not yet clear what exactly caused this - but it is not possible to exclude that Icelandic financial enterprises and black foreign money were involved".

Gunnar continues and raises some questions about that year's developments, at home and abroad:

Why did the U.S. Federal Reserve Board not want to assist the Central Bank of Iceland?

Why were Icelandic authorities reluctant to seek out the IMF?

Why did the United Kingdom apply terrorist law against the National Bank of Iceland?

Why has Geir Haarde, former Prime Minister of Iceland, not spoken with Gordon Brown, former Prime Minister of UK, since then?

Why won't Davíð Oddsson, former Primes Minister of Iceland and former Governor of CBI, express his view on this point?

Why are Icelandic authorities reluctant to submit their dispute with the United Kingdom to a court of law?

Why did the Russian ambassador mention a \$ 4 billion loan to Iceland?

Why did Icelandic authorities take this point seriously?

in this context is tax evasion and the shaping of the tax rules.

Three committees have been given the task of looking into the size and scope of tax evasion in Iceland. In addition, two other committees worked on tax evasion; one during the period 1994 and 1997, since the government wanted to change the public attitude towards tax evasion, and in 2000, a committee studied the workings of the VAT system. Here, we are only concerned with the three committees (1986, 1993 and 2004) that estimated the size of the Non-Observed Economy (NOE). Their proposals did not result in legislation. The Independence Party and the Progressive Party, which were in government, obviously found other tasks more pressing ${ }^{6}$.

6 Three committees have been given the task of looking into the size and scope of tax evasion in Iceland. The first committee estimated tax evasion to be between 5 and 7 per cent of GDP, the second one 4.25 per cent of GDP and the third one estimated tax evasion to be between 3 and 5 per cent of GDP. The last two committees were composed of top officials of the tax authority. The first committee proposed improvement of the education of tax-office employees. The committee suggested the establishment of a special governance school and to create a special force of 5 to 7 men to examine those sectors in which tax evasion and tax avoidance were likely to occur, i.e. to investigate the 'big fish'. The first two committees used the difference between GDP measured by the production and the expenditure methods to measure the GDP as a means for assessing the Non-Observed Econ-
The authorities' relaxed attitude towards fraud and corruption led to spectacular instances of tax evasion in the run-up to the crisis 2008. In 2005, the Directorate of Internal Revenue (DIR) established a special force in order to examine the 'big fish'. At the same time, the DIR charged the Icelandic banks (Glitnir, Kaupthing Bank and Landsbanki Îslands) with encouraging their customers to practice tax evasion by lending them funds so that they could buy shares in the same banks, without reporting such transactions to the DIR. On the 30th of March 2006, the District Court of Reykjavík ruled in favour of the DIR, but six months later, the General Director of Directorate of Internal Revenue in office was replaced. On the $8^{\text {th }}$ of March 2007, the Supreme Court confirmed the Discrict Court's ver$\mathrm{dict}^{7}$. According to this verdict, 127 billion ISK were not accounted for in the tax returns, roughly the equivalent of 10 percent of the GDP of the year 2003, while the capital tax would have been somewhere between 3 and 6 billion ISK, not counting the fines that might have been imposed. Yet no one was prosecuted for tax evasion or for encouraging customers to practice tax evasion (Karlsson (2010)).

\subsection{The Crisis of 2008: Fiscal Fraud and Money Laundering}

In 2005, the then recently privatized Icelandic banks (Glitnir, Kaupthing Bank and Landsbanki Îslands) took 14 billion Euros worth of loans in foreign currencies (roughly the equivalent of the GDP for that year), which was a 100 per cent increase from the previous year; and it was obvious from the onset that they would have difficulties repaying them (Special Investigation Commission (2010b, pp. 3234)). Several aspects of the operations of the three main Icelandic investors-pension funds, Icelandic Fishing Vessel Owners, and the banks-remain unclear to date; yet, according to the findings that are being tested in the District Court of Reykjavik (summer 2015), it appears that an im-

omy (NOE), while the third committee applied a method developed in Scandinavia to Iceland, using adapted figures from Sweden and Denmark to Iceland (Alpingi (1986, 2005); Fjármálaráðuneyti (1993)). The data were obtained from the now defunct National Economic Institute. According to the third committee, Statistics Iceland published only GDP figures based on the expenditure approach. Therefore, the third committee could not use the same method as the two former committees. The same applies to the present authors; we have to use other methods for periods later than 1997.

7 Following that verdict, Statistics Iceland had to recalculate the bank deposits of all Icelandic taxpayers for the period from 2000 to 2008. 
portant part of this system was the use of the currency market as a tool for fraud and money laundering by transferring money to tax havens and then back again to invest in Icelandic companies with no taxes being paid to any state ${ }^{8}$ (see Box 2) (Tómasson (2009); Porláksson (2008)).

By granting their customers loans in order to buy shares, the Icelandic banks were able to expand their balance sheets by issuing new series of bonds. The bonds issued by one bank were subsequently used by another bank as collateral in an ever-increased repo trade with the CBI. From 2006 to 2008, there was an increase in the number of bonds issued, from a worth of 20-billion ISK to 300billion ISK (Special Investigation Commission (2010a, pp. 162-166)). The banks were actually allowed to print bank notes as needed, with the implicit authorization of CBI. By so doing, the banks were in fact attempting to repay the foreign currency loans. According to the Icelandic National Audit Office lack of response from the CBI did cost the Icelandic taxpayers around 400-billion ISK (4-billion Euro) or 25 per cent of the GDP of 2008 (Ríkisendurskoðun (2009)) $)^{9}$.

Let us look at another, unrelated matter. It might be a coincidence that the financial accounts of Iceland for 2003 show an unexplained financing of the Icelandic economy, amounting to 127 billion ISK (as adjusted by Statistics Iceland, (see Box 2, item 9 in table), roughly the equivalent of 10 per cent of the GDP. The items that seem to be most out of synch compared to 2002 and 2004 are net lendings to households and increases in household deposits (see Box 2, Items 8.1.1. and 8.2.1

\footnotetext{
8 In October 2010, the French Finance Minister, Christine Lagarde, passed a list on to Greek officials to help them crack down on tax fraud and money laundering. It was only two years later the list became known to a wider public when a journalist published it. The Lagarde list is only a subset of a much larger data set known as the Falciani list, with around 130,000 names of HSBC customers retrieved by the French police. However, the Greek tax authorities chose not to proceed, although the case is not closed. The same course of events occurred in Iceland. The Directorate of Tax Investigation (DTI) was offered to buy a list containing names of wealthy Icelandic depositors in tax havens in order to enable the Icelandic government to crack down on tax fraud money laundering in 2014, see Box 2. The Icelandic Finance Minister (since 2013), did not make this matter a priority, but following media pressure, he finally accepted the to buy the list, but only if the DTI would consult with the Ministry about the investigation. Finally, the DTI investigated only 30 persons out of 400 on the list. Subsequently, the DTI has made a proposal, which, if adopted by the Parliament, will grant the listed fraudsters an amnesty, provided they admit of their own accord that they are on the list before the DTI summons them (Fjármálaráðuneyti (2015); Wikipedia (2015a)).

9 The total bill to be paid by each familly is around five million ISK, or two years of a workers salary.
}

To sum up, circumstantial evidence indicates that there were two different money-laundering systems at work, a domestic one, and another one for foreign capital.

\subsection{Evidence on Tax Evasion since 2000}

Although numbers alone can never reveal reality, numerous and frequent amendments and particular tax-law revisions indicate economic instability, tax evasion and corruption. Between 1938 and 1958, there were 400 taxlaw amendments made in Iceland, while between 1975 and 2010; there were 700 tax-law amendments. We can compare Iceland to another crisis-ridden country, Greece, where 250 similar amendments were made between 1975 and 2010, not counting other related laws (Boukalas (2015)). Now, amendments can be made to close loopholes, and amendments can also open new back doors.

The evidence indicates that neither tax investigations nor tax controls were high on the agenda of the Icelandic Ministry of Finance, (see Tables 1, 2, and 3). The Directorate of Tax Investigations (DTI) is responsible for the tax investigation, while the Directorate of Internal Revenue (DIR) is responsible for the tax control. The DTI investigated no cases related to tax havens between 2000 and 2008, while the DIR investigated 130 cases during that period (after the establishment of the special force unit in 2005). The first thing the new government did in 2009, after the 2008 crisis, was to strengthen tax controls (see Tables 1 and 7) by increasing funding to the directorates.

As shown in Table 1, during the year 2000, fines due to tax fraud were $0.04 \%$ of government revenue (126 billions of ISK in 2000 prices), based on the work of 34.9 full timers in control and 20 full timers working on a more specific basis. Revenue from tax fraud controls and investigations increased dramatically in the aftermath of the 2008 bank crash, even if employment in control and investigation remained fairly stable, and in 2010, the total tax penalties amounted to 0.31 percent of all taxes, which came mostly via the Courts.

As shown in Table 2, there are 194 open cases in end of the year 2000, 13 were penalized for evasion, 44 for unpaid taxes and of 251 persons, 214 were penalized. In 2008, 82 cases were open at the end of the year, 73 were penalized for evasion, 76 for unpaid taxes, and of 231 persons, 188 are penalized.

As shown in Table 3, there was a total of 1611 investigations made in 2000, thereof the initiated cases were 578 , closed cases 351, assessed cases 551 and open cases by the end of the year 131. In 2009, the total number of the cases 
Table 1: Total Tax Fines in ISK and Annual Labor Unit in Tax Control and Tax Investigation 2000-2013.

\begin{tabular}{lccccccc}
\hline & & & \multicolumn{3}{c}{ Fines } \\
\cline { 4 - 8 } & \% of Govern. & Total & Courts & SIRB & DTI & Control & Investigation \\
\hline Total & $\mathbf{0 , 1 5}$ & $\mathbf{1 2 . 1 6 9 . 6 3 3 . 7 1 8}$ & $\mathbf{4 . 3 7 4 . 6 0 3 . 7 1 8}$ & $\mathbf{1 . 5 6 9 . 8 9 5 . 0 0 0}$ & $\mathbf{3 2 4 . 1 5 0 . 0 0 0}$ & $\mathbf{3 3 , 9}$ & $\mathbf{2 3 , 5}$ \\
2013 & 0,22 & 1.748 .710 .000 & 1.416 .620 .000 & 298.630 .000 & 33.460 .000 & 29,0 & 28,2 \\
2012 & 0,16 & 1.179 .631 .000 & 856.391 .000 & 264.800 .000 & 58.440 .000 & 30,0 & 29,2 \\
2011 & 0,15 & 991.660 .000 & 718.395 .000 & 239.055 .000 & 34.210 .000 & 30,0 & 30,4 \\
2010 & 0,31 & 1.980 .984 .000 & 1.386 .544 .000 & 548.840 .000 & 45.600 .000 & 30,0 & 30,1 \\
2009 & 0,19 & 1.167 .413 .000 & 794.673 .000 & 319.910 .000 & 52.830 .000 & 32,2 & 21,4 \\
2008 & 0,16 & 1.060 .991 .000 & 851.811 .000 & 126.560 .000 & 82.620 .000 & 33,0 & 20,4 \\
2007 & 0,10 & 601.701 .387 & 314.501 .387 & 193.830 .000 & 93.370 .000 & 33,7 & 18,2 \\
2006 & 0,16 & 872.709 .323 & 542.954 .323 & 234.425 .000 & 95.330 .000 & 40,1 & 22,7 \\
2005 & 0,16 & 749.720 .000 & 575.150 .000 & 174.570 .000 & & 37,9 & 24,1 \\
2004 & 0,11 & 446.762 .000 & 364.552 .000 & 82.210 .000 & & 35,4 & 23,3 \\
2003 & 0,16 & 590.416 .000 & 493.836 .000 & 96.580 .000 & & 34,7 & 20,0 \\
2002 & 0,09 & 291.583 .000 & 118.958 .000 & 172.625 .000 & & 37,6 & 20,6 \\
2001 & 0,11 & 360.543 .008 & 233.468 .008 & 127.075 .000 & & 36,4 & 20,0 \\
2000 & 0,04 & 126.810 .000 & 84.700 .000 & 42.110 .000 & & 34,9 & 20,0 \\
\hline
\end{tabular}

Source: The Ministry of Finance, Statistics Iceland

Notes:

$\mathrm{SIRB}=$ The State Internal Revenue Board. DIR = Directorate of Internal Revenue. DTI = The Directorate of Tax Investigations. $\%$ of Govern ${ }^{\star} .=$ Percent of General Total Revenue and Average for 2000-2013.

However, according to the Statement of General Government Operations tax penalties 2000-2012 were in ISK:

\begin{tabular}{cccccc}
\hline $\mathbf{2 0 0 0}$ & $\mathbf{2 0 0 2}$ & $\mathbf{2 0 0 4}$ & $\mathbf{2 0 0 5}$ & $\mathbf{2 0 0 6}$ & $\mathbf{2 0 0 7}$ \\
\hline 50.000 .000 & 210.000 .000 & 110.000 .000 & 190.000 .000 & 270.000 .000 & 250.000 .000 \\
$\mathbf{2 0 0 8}$ & $\mathbf{2 0 0 9}$ & $\mathbf{2 0 1 0}$ & $\mathbf{2 0 1 1}$ & $\mathbf{2 0 1 2}$ & \\
\hline 180.000 .000 & 350.000 .000 & 550.000 .000 & 230.000 .000 & 310.000 .000 & \\
\hline
\end{tabular}

(Figures are not available for 2001 and 2003)

According to Article 109 of Income Tax Act No 90 of 2003:

"If a person, that is obliged to submit a tax return, on purpose, or out of gross negligence, makes false or misleading statements about something that matters in relation to its income tax it is to pay monetary damage up to tenfold the tax amount from the tax base that was evaded and never lower monetary damage than double the tax amount”.

Table 2: Number of cases by category investigated 2000-2009.

\begin{tabular}{ccccccc}
\hline & & \multicolumn{5}{c}{ Categories } \\
\cline { 3 - 6 } & Total & Thereof penalized & Evasion & Unpaid Taxes & Other & Open Cases \\
\hline Total & $\mathbf{3 . 0 8 4}$ & $\mathbf{1 . 5 0 1}$ & $\mathbf{5 2 6}$ & $\mathbf{8 0 0}$ & $\mathbf{1 1}$ & $\mathbf{1 . 7 4 7}$ \\
2009 & 265 & 163 & 47 & 76 & 0 & 142 \\
2008 & 231 & 188 & 73 & 76 & 0 & 82 \\
2007 & 367 & 162 & 84 & 75 & 0 & 208 \\
2006 & 366 & 154 & 84 & 72 & 0 & 210 \\
2005 & 270 & 176 & 54 & 78 & 0 & 138 \\
2004 & 372 & 121 & 46 & 103 & 1 & 222 \\
2003 & 221 & 103 & 58 & 96 & 8 & 59 \\
2002 & 380 & 120 & 31 & 99 & 2 & 248 \\
2001 & 361 & 100 & 36 & 81 & 0 & 244 \\
2000 & 251 & 214 & 13 & 44 & 0 & 194 \\
\hline Source: The Ministry of Finance
\end{tabular}


Table 3: Tax control by category 2000-2009.

\begin{tabular}{cccccc}
\hline & Total & Initiated Cases & Closed Cases & Assessed Closed & Open Cases \\
\hline Total & $\mathbf{2 7 . 0 2 9}$ & $\mathbf{1 0 . 8 1 2}$ & $\mathbf{1 0 . 3 1 9}$ & $\mathbf{5 . 2 6 8}$ & $\mathbf{6 3 0}$ \\
2009 & 3.695 & 1.327 & 1.645 & 631 & 92 \\
2008 & 3.315 & 1.463 & 1.272 & 543 & 37 \\
2007 & 3.697 & 1.370 & 1.466 & 833 & 28 \\
2006 & 3.297 & 1.359 & 1.351 & 561 & 26 \\
2005 & 3.169 & 1.302 & 1.302 & 490 & 75 \\
2004 & 2.598 & 1.184 & 1.001 & 383 & 30 \\
2003 & 2.112 & 832 & 832 & 411 & 37 \\
2002 & 1.976 & 879 & 670 & 388 & 39 \\
2001 & 1.559 & 518 & 429 & 477 & 135 \\
2000 & 1.611 & 578 & 351 & 551 & 131 \\
\hline Source: The Ministry of Finance & & & &
\end{tabular}

Table 4: Rulings of the Supreme Court of Iceland 2000-2009.

\begin{tabular}{lccc}
\hline & Total & Evasion & Defaults \\
\hline Total & $\mathbf{5 4}$ & $\mathbf{1 1}$ & $\mathbf{4 3}$ \\
2009 & 2 & 0 & 2 \\
2008 & 2 & 1 & 1 \\
2007 & 19 & 0 & 19 \\
2006 & 11 & 2 & 9 \\
2005 & 1 & 0 & 1 \\
2004 & 0 & 0 & 0 \\
2003 & 4 & 3 & 1 \\
2002 & 2 & 1 & 1 \\
2001 & 3 & 2 & 1 \\
2000 & 10 & 2 & 8 \\
\hline Source: The Ministry of Finance & &
\end{tabular}

Table 5: Rulings by the District Courts of Iceland 2000-2009.

\begin{tabular}{lccc}
\hline & Total & Evasion & Defaults \\
\hline Total & $\mathbf{3 0 4}$ & $\mathbf{1 3 4}$ & $\mathbf{1 7 0}$ \\
2009 & 36 & 23 & 13 \\
2008 & 45 & 24 & 21 \\
2007 & 22 & 9 & 13 \\
2006 & 39 & 10 & 29 \\
2005 & 44 & 14 & 30 \\
2004 & 23 & 3 & 20 \\
2003 & 21 & 10 & 11 \\
2002 & 18 & 6 & 12 \\
2001 & 30 & 17 & 13 \\
2000 & 26 & 18 & 8 \\
\hline Source: The Ministry of Finance & &
\end{tabular}

had more than doubled, or increased to 2695 , thereof there
Table 6: Verdicts of The State Internal Revenue Board 2000-2009.

\begin{tabular}{lccc}
\hline & Total & Evasion & Defaults \\
\hline total & $\mathbf{5 7 8}$ & $\mathbf{2 0 7}$ & $\mathbf{3 7 1}$ \\
2009 & 76 & 42 & 34 \\
2008 & 49 & 26 & 23 \\
2007 & 52 & 19 & 33 \\
2006 & 83 & 18 & 65 \\
2005 & 58 & 21 & 37 \\
2004 & 39 & 19 & 20 \\
2003 & 43 & 10 & 33 \\
2002 & 79 & 9 & 70 \\
2001 & 74 & 34 & 40 \\
2000 & 25 & 9 & 16 \\
\hline
\end{tabular}

were 1327 initiated cases, closed cases 1645 , assessed cases 631, and 92 open cases by the end of the year.

As shown in Tables 4, 5 and 6 the rulings for tax evasion by the Supreme Court and the District Courts and the verdicts for tax evasion by the State Internal Revenue Board (SIRB) did not change after the financial crisis 2008, mostly because these cases are difficult and some of them remain unresolved. From 2000 to 2009, the Supreme Court of Iceland rendered on average 1.1 ruling per year for tax evasion, the District Courts rendered 13.4, and the SIBB rendered an average of 20.7 verdicts for tax evasion per year. The same applies to the defaults.

As shown in Table 7, tax control is much more efficient than the investigation. In 2005, tax investigation returned 21.6 million ISK; while the tax control returned 33 million ISK; or 52 per cent more than the tax investigation. In 2009, this rate was 850 per cent. An uninformed reader may find it surprising that the DIR dismantled its tax control depart- 
Table 7: Comparing tax controls and tax investigation per empleyee 2003-2009.

\begin{tabular}{lcccccc}
\hline & \multicolumn{2}{c}{ Control } & \multicolumn{2}{c}{ Investigation } & \multicolumn{2}{c}{ Control/Investigation } \\
\cline { 2 - 7 } & Overall changes & $\begin{array}{c}\text { Loss } \\
\text { Carryforward }\end{array}$ & Overall changes & $\begin{array}{c}\text { Loss } \\
\text { Carryforward }\end{array}$ & $\begin{array}{c}\text { Overall } \\
\text { changes }\end{array}$ & Carryforward \\
\hline Total & $\mathbf{1 2 5 . 6 5 3 . 7 1 9}$ & $\mathbf{2 5 2 . 0 0 9 . 8 1 8}$ & $\mathbf{1 1 . 7 5 6 . 9 1 9}$ & $\mathbf{9 . 0 6 7 . 9 0 7}$ & $\mathbf{1 0 6 8 , 7 6}$ & $\mathbf{2 7 7 9 , 1 4}$ \\
2009 & 89.271 .332 & 39.413 .222 & 9.405 .056 & 3.092 .214 & 949,18 & 1274,60 \\
2008 & 82.849 .319 & 267.072 .646 & 17.232 .463 & 9.462 .105 & 480,77 & 2822,55 \\
2007 & 48.543 .103 & 31.046 .553 & 23.219 .713 & 4.791 .112 & 209,06 & 648,00 \\
2006 & 74.322 .103 & 15.670 .339 & 15.901 .167 & 75.234 .864 & 467,40 & 20,83 \\
2005 & 33.018 .741 & 15.636 .802 & 21.699 .455 & 8.343 .967 & 152,16 & 187,40 \\
2004 & 19.562 .344 & 1.888 .315 & 71.180 .181 & 6.236 .449 & 27,48 & 30,28 \\
2003 & 11.474 .745 & 2.760 .373 & 17.275 .136 & 28.954 .268 & 66,42 & 9,53 \\
\hline
\end{tabular}

Source: The Ministry of Finance, Karlsson (2010).

Notes:

Investigation $=100$

Directorate of Internal Revenue (DIR) is responsible for the tax control, while, the Directorate of Tax Investigations (DTI) is responsible for the tax investigation. Tax controls ate obviously much more effective than tax investigation per employee. The is especially true from 2009 , when a special force, that was founded in 2005, in spite of the government's fierce opposition (Independence Party) began to produce results. From 2000 to 2004 there were 3 control units, thereof 1 in the hands of DIR, while the Minister of Finance decided to decentralized the tax control, and in 2007 the DIR weakened the tax control further. The first thing the new government did in 2009, after the 2008 crisis, was to strengthen tax controls.

ment in 2007. The Sigurdardóttir government (2009-2013) strengthened the tax controls partly as a response to the crisis of 2008.

\section{Tax Inspection: Ineffective by construction?}

\subsection{Introduction}

As we described in the last section, indicators suggest that tax fraud in Iceland has been considerable over a long period, especially in the 1940 s and in the run-up to the crisis of 2008. Hence, it may seem strange that it was not until 1970 that the first tax fraud case was processed in the Supreme Court of Iceland. Since the year 2000, there have only been, on average, 1.1 rulings on tax fraud each year (see Table 5) or 3.3 per million inhabitants. A comparable figure from the UK is 600 per year since 2012 or 10 per million (Financial Times (2013)). The integration of the tax administration with the political sector did probably not help to prioritize surveillance.

The second reason lies in the organization and the operation of the government. The government did not have formal procedures and controls governing the execution of the budgetary policy until $1966^{10}$, and there was no law governing the executive branch of the government until 1969. Yet much of the organizational confusion that existed in the government, much of the delay in adopting modern methods of budgeting and accounting, and much of the failure to perceive the need for long-term program planning, might be attributed, at least in part, to the fact that no one had been trained specifically for administration of government services. The personnel administrating the taxation system were no exception.

\subsection{Outside advice}

One of the pieces of advice given as Iceland joined the Marshall Plan in 1950 was to have an outside expert to

10 Iceland has always had a poor track record for enforcing budget discipline. Supplementary budgets are now submitted during the budget year, whereas earlier they were submitted a year or two or three after the fact. The supplementary budget as a percentage of the total expenditure has been very high most of the time. This is partly due to unpredicted inflation but is also a symptom of clientelism. From WWI to the end of WWII, Iceland overspent its annual budget by an average of 33.2 percent, and from WWII to 1959, Iceland overspent its annual budget by an average of 13.3 percent. In the 1970s, Iceland overspent its annual budget by an average of 18.3 percent, and during the decade leading up to the 2008 crisis, Iceland overspent its annual budget by an average of 12 per cent (Blöndal $(1965,1983)$; IMF (2012)). 
examine the fiscal system of Iceland. The Icelandic fiscal system was unusual compared to that of other countries, inasmuch as the national system of taxation was highly regressive. In 1950, sales taxes and customs duties were around 56 percent of the national government's revenue, the wine and tobacco monopolies accounted for a further 23 percent, while direct income taxes were only around 13 percent (Clark (1951)). Various industrial players, wholesalers, shop owners, the Union of the Icelandic Employers (VSÍ) and the Chamber of Commerce of Iceland, not trusting the Government (the alliance of the Progressive Party and the Independence Party) to change the taxation system, sought independent analysts to undertake research on corporate taxation in 1956. In 1958, dr. Nils Wästhagen, a Swedish specialist from the OEEC suggested changes to the taxation system, and most of them were adopted (OEEC (1958)). According to Wästhagen, the tax system was a mess. Its administration was very complicated, and the national system of taxation was highly regressive. The taxes from the companies of the Fishing Vessel Owners Organization (LÍU), were between 2 or 3 percent of the State income (and this has not changed much over the years). Annual reports of companies were not collected by the State. Definitions of basic concepts in the accounting standards were flawed, so, for example, in 1957 the trawler companies supposedly paid 140 per cent of their profits in total taxation, and the fish plants supposedly paid 178 per cent of their income in total taxation.

The tax legislation for companies was not aligned with that of other countries until Iceland joined EFTA in 1970, and the tax legislation for individuals was only harmonized with international practices in 1980; but the legislation for companies was incomplete until 1995, with Acts No 138 (respecting Private Limited Companies) and 145 of 1994. In accounting, the first Acts about double-entry accounting were No 62 of 1938 and then No 51 of 1968, and No 2 of 1995 (respecting Limited Companies).

\subsection{Human Resource Management at the Tax Office}

In the 1950s, tax administration was a much bigger part of government than it is now. Back then, about one of four state employees worked on taxation (800 persons). In 2014, the number had halved to 400 and the share of state employment had shrunk by a factor of 10 (400/17000). In the 1950s, the salaries of state employees were determined by an act of law. Each position was assigned to one of sixteen salary ranges established by that act. Salaries increased automatically within the salary range, based on age and years of service, so it normally required four to six years to go from the minimum to the maximum salary within each range. No attendance or leave records were maintained, and salary payments were made monthly. No law or regulation was in force on qualifications of new recruits or working conditions of the recruited until the adoption of the Act of Civil Servants No 38 of 1954, following the recommendations of the IMF. The first administration school was founded in 2010 (post crash), following the recommendations of the Special Investigation Commission (Government (2010)). Until 1962, the tax administration was organized geographically, by municipalities and counties and not by tax type. In other words, in each of the 200 municipalities and in each of the 24 counties in the country, the staff had to oversee the compliance with all the different chapters of the tax code. A National Registry, maintaining, inter alia, a register of potential tax entities, was established in 1952, following IMF recommendations (PAS (1950)). Taxes to the central government were assessed via the computer system used to administrate the National Registry from 1965, even if the computer system was in place earlier.

\subsection{Institutional setup and changes}

The form of the local tax administration was the model for the national tax administration. Until 1960, there were special, three-person tax committees in each rural district that assessed income taxes, and in each town or district there were so-called general tax committees, also threeperson strong. If a taxed entity (person or legal person) believed its taxes or tax base, including operating losses, wrongly assessed, it could file a reasoned appeal to the appropriate tax committee. If the taxed entity still believed its taxes were wrongly assessed, it could file a reasoned appeal to the Minister. In 1932, the State Internal Revenue Board (SIRB), with three members, was established. The SIRB ruled cases of disagreement between a tax-payee and the relevant tax office. Thus, there were four tax administration levels, and consequently, the tax administration was both complex and inefficient. From 1928 to 1960, the Parliament had appointed ten committees to redesign the system, with scarce results, until 1962, when the Directorate of Internal Revenue was established. The DIR was organized geographically between 1962 and 2009. From 2010, the DIR has been organized as one unit that has increased its ability to specialize. The main function of the DIR has been tax assessment.

Since 2010, administration of matters related to taxation is organized on three levels: the Finance Minister is 
Table 8: Yearly Population Growth, Economic Growth and CPI by Taxation Periods 1929-2009.

\begin{tabular}{|c|c|c|c|c|c|c|c|}
\hline \multirow{2}{*}{ 운 } & \multirow{2}{*}{$\begin{array}{c}\text { Population, } \\
\%\end{array}$} & \multirow{2}{*}{$\begin{array}{l}\text { Frowth } \\
\text { rate, \% }\end{array}$} & \multirow{2}{*}{$\begin{array}{l}\text { Growth rate } \\
\text { per capita, \% }\end{array}$} & \multirow{2}{*}{ CPI, \% } & \multicolumn{2}{|c|}{ Income rax, \% } & \multirow{2}{*}{$\begin{array}{l}\text { Indirect taxes as a } \\
\text { share of total taxes }\end{array}$} \\
\hline & & & & & Average & Marginal & \\
\hline 1 1929-1941 & 0,92 & 0,32 & $-1,12$ & 5,38 & 18,36 & 50,28 & 61,01 \\
\hline $21941-1954$ & 1,84 & 7,51 & 7,58 & 11,97 & 13,17 & 91,00 & 60,84 \\
\hline $31954-1960$ & 2,17 & 4,25 & 1,90 & 6,47 & 20,60 & 40,40 & 52,50 \\
\hline $41960-1972$ & 1,46 & 5,42 & 3,91 & 12,83 & 18,89 & 30,30 & 73,52 \\
\hline 5 1972-1979 & 1,09 & 5,51 & 4,38 & 38,46 & 29,66 & 44,00 & 79,54 \\
\hline 6 1979-1988 & 1,14 & 3,74 & 2,37 & 40,29 & 34,10 & 51,00 & 71,55 \\
\hline 7 1988-1997 & 0,90 & 1,37 & 0,46 & 6,52 & 32,38 & 39,30 & 61,06 \\
\hline 8 1997-2007 & 1,40 & 4,43 & 3,22 & 2,94 & 26,14 & 34,41 & 53,63 \\
\hline 9 2007-2009 & 0,30 & $-1,74$ & $-4,04$ & 14,13 & 23,20 & 32,10 & 46,00 \\
\hline
\end{tabular}

Source: Karlsson (2014)

Notes: The taxation periods are based on fundamental changes in the marginal tax rates and tax base of the income tax to the central government.

the highest, the State Internal Revenue Board is in between and the Directorate of Internal Revenue is the lowest or first level.

\subsection{The Taxation Policy and its Effect on Economy}

The structure of the local tax system remained almost unchanged from 1809 to 1960 . Taxation was not based on rules defining a tax base and linking taxation to that base, but on the varied and variable needs of local governments for funds. Reforms in the 1960s and 1970s brought in more rule and order, but the variability of local government needs has been met with a complex transfer-system.

Icelanders have based the income taxation on either the Dual Income Taxation System (DIT-system), or the Comprehensive Income Taxation System (the CIT-system). From 1930 to 1996, there was a CIT-based-system. This system was originally based on the Danish tax system from 1903 and is also reflected in the current Act No 90 from 2003, amended numerous times (especially by Act No 20 of 1942, changed to gross income tax, No 68 of 1962 and No 3 of 1971, tightening the tax collection, No, 40 of 1978, income taxed per person instead of per home and selfemployed taxed, and No 45 of 1987, withholding of public levies at source).

The Icelandic DIT-system came into force in January 1997 , Nordic in spirit but based on light progression compared with other Nordic countries (Karlsson (2014); Kukkonen (2008)).

Icelandic tax revenue has been characterized by a heavy dependence on import duties, and until the 1980s, no less than 60 to 85 per cent of the total revenue was col- lected in this form. Iceland increased tariffs on imports in the 1920s. These tariffs were both source of income for the state and shelter for domestic producers. A step towards increasing the share of indirect taxation was the introduction of general sales tax in 1960. As Iceland joined the EFTA in 1970, some changes were made to the form of the indirect taxation and the equivalent of tariffs levied on imports and domestic production alike (excise taxes to be abolished in early 2016). In 1990, Iceland changed from a general sales tax to a value added tax, as the general sales tax was hard to administer.

The years 1930-2009 can be divided into 9 periods, referenced to changes in marginal tax rates and the tax base. From 1930 to 2009, the GDP growth per capita per year has neither been steady nor high; this was partly due to non-diversification of the economic activity, with fisheries as the dominant sector, and partly to the general lack of fiscal policy. Exceptions appear during the period 19411954, when the average growth rate was 7.6 per cent per year, and during the period 1960-1979, see Table!8. This state of affairs had very little to do with taxation policy or tax rates of the income tax, which were responses to the economic situation rather than the reflection of any planning by the government for the economy or the people. The growth during the period 1941-1954 was the consequence of the Allied occupation (see Chapters 2.2 and 3,2), and the growth during the period 1960-1979 was the consequence of the overfishing or the overexploitation of fish stocks.

From period 1 to period 5, indirect taxes as a share of total taxes rose from 50 per cent to 80 per cent, and the tax burden of the lower class became much higher than that of the upper class, even though the highest marginal tax rate was 91 per cent (Period 2). The fiscal policy of the Government was not based on streamlining the tax code. 
High inflation, in excess of 40 per cent a year during part of the period 5 and 6 , secured increased tax revenue as lower income recipients entered higher and higher tax brackets. Obviously, this is an intricate process, as neither assets nor liabilities were indexed until 1979 (period 6). Therefore, those who had money in banks lost their assets, and those who had debts gained, for instance by property transfers between generations. Since 1988 (period 7), the tax base has mostly been unchanged and the rate of the indirect taxes as a share of total taxes has fallen. By changing to the DIT-system in 1997 (period 8), the income taxes on individuals increased, while they decreased on companies. The plan was to transform Iceland into a tax haven (see Chapter 2.6) by lowering the highest marginal tax rate to 15 per cent, which made the crisis of 2008 even worse than it might otherwise have been, as there was no liquidity available.

\subsection{Being too efficient has its costs}

The reorganization of the tax administration in $1962 \mathrm{did}$ not accommodate the fact that a sales tax had been adopted in 1960. The collection of the sales tax was in the hands of merchants who where obliged to fill in forms and send reports. The compliance was less than satisfactory. The local tax officers had few means of control. Every merchant had his own rulebook for registration of transaction, or no rule at all.

In 1964, the Finance Minister established the new Tax Investigation Office, complemented by a Tax Penalty Committee. However, his decision to create a Tax Police, as it was usually named, caused great controversy within the Independence Party, and he was replaced. The new Minister of Finance was appointed in the midst of the second debate of the bill about the Tax Penalty Committee. On May $11^{\text {th }}$, the last working day of the Parliament before summer vacation, the bill was changed and total indulgence granted to all tax fraudsters, both those who had committed fraud related to the income tax code and also those who had committed fraud related to the sales tax code. The changed bill did not only grant them indulgence, but also further, tax fraudsters did not have to pay any taxes at all on the extra money they had obtained illegally. Many MPs considered this an affront to the taxpayers' sense of justice. However, this indulgence became Act No 70 of 1965. At the same time, the Finance Minister reduced the mandate of the tax authorities to investigate tax evasion retrospectively (first to 10 years back, then to 6 years).

The Tax Investigation Office began to compare reports from the wholesalers with the figures from the local mer- chants. This was a successful line of investigation (see figure 3, year 1965-1967), but the new Minister of Finance did not provide the resources necessary to continue, as the Director was supposedly not cooperative enough, and according to the Director, he and his family were also threatened by some of the 'big fish'. Therefore, he decided to quit the job after only two years. However, he had booked some cases with the courts, cases that did not pass through swiftly.

It is evident that the system itself slowed down the process in every possible way. The tax investigation started in 1965 and ended in 1967, when the Public Prosecutor issued an indictment for income tax fraud, sales tax fraud, and falsified bookkeeping. Still, in 1968, the accused asked the Supreme Court for re-examination because the judge had not had special experts to examine the case with him. Finally, in 1970, the District Court in Reykjavik found the accused guilty of all charges, and the Supreme Court confirmed the verdict a few months later, (Hrdr 115 (1970)).

Those who are regulated do not operate in a vacuum, and regulators need a lot of industry-specific information so they can do their job properly. Therefore, the regulator tries to establish a cooperative relationship with the regulated. This also applies to the special interest groups that infiltrate the administration system with 'their' men. The Independence Party has almost single-handedly directed the Ministry of Finance since 1959 (see Figure 4).

In 1992, the State Internal Revenue Board (SIRB) rendered two verdicts that have proven pivotal. A special interest group had intended to let taxpayers pay the debts of the Progressive Party by using loopholes in the tax system. The verdict blocked that intent. A second verdict concerned the taxation of fishery quota benefits. Following these verdicts, the SIRB was immediately shut down and dismantled, whereupon a new institution was founded and staffed with fresh personnel. At the same time, all tax investigations were taken from the Directorate of Internal Revenue (DIR) and became the main task of a brand new institution, the Directorate of Tax Investigations (DTI) (see Tables 1 - 7).

The repartition of the authority between offices in the tax system is as follows: the Directorate of Internal Revenue (DIR) imposes taxes, the Directorate of Tax Investigations (DTI) investigates tax frauds, and the State Internal Revenue Board (SIRB) determines tax fines in those cases where fines have been imposed by the DTI. In other words, when the DTI finds frauds, it always sends the DIR the case for review, but it depends upon the details of the cases which way they go from there: the lesser ones go to the SIRB, while the substantial ones are referred to the State Public Prosecutor. Nevertheless, even after the financial 

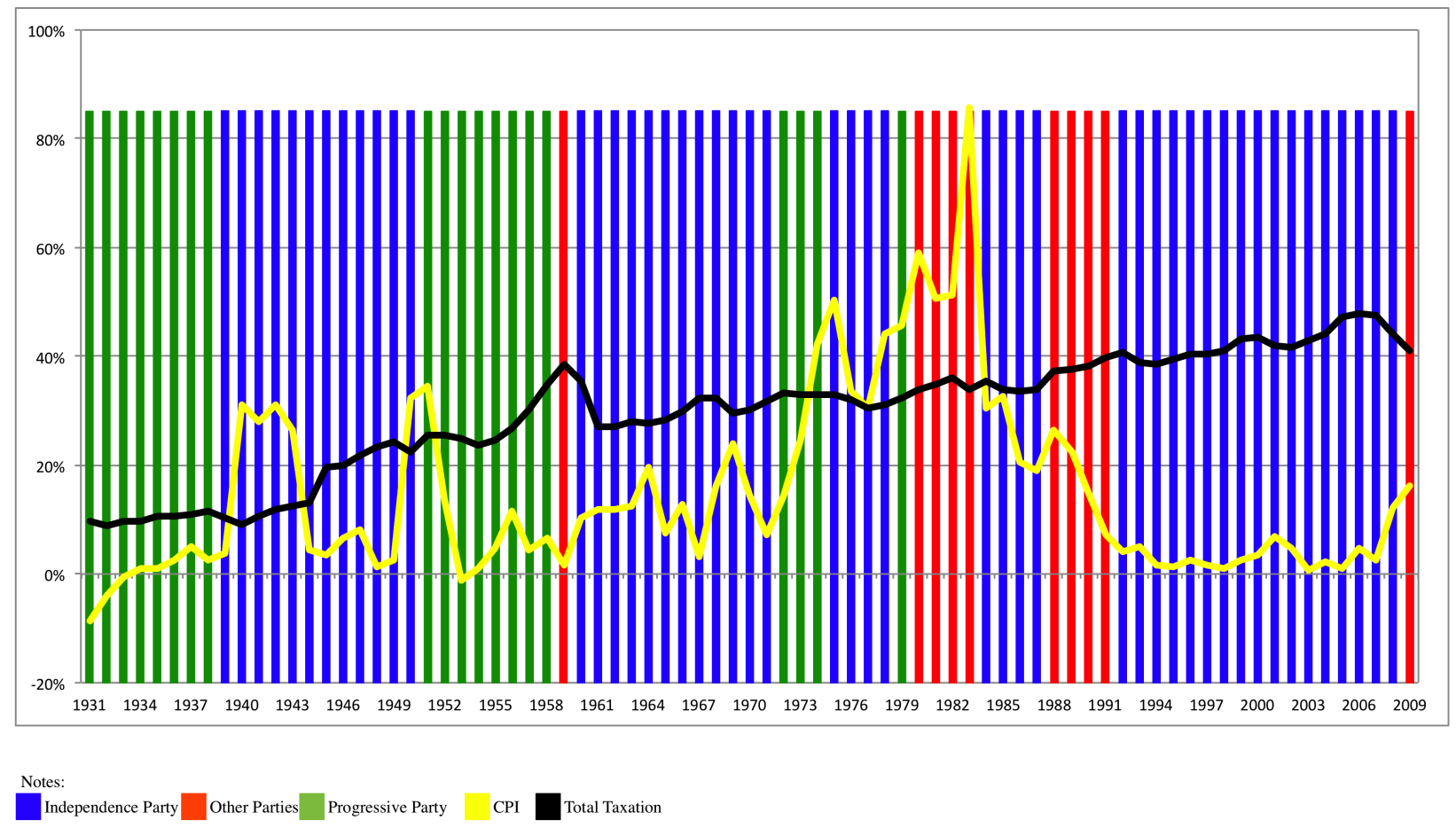

Sources: Ministry of Finance, Statistic Iceland

Figure 4: Finance Ministers by Political Parties, Total Taxation as \% of GDP and CPI 1931-2009.

crisis of 2008 , this does not seem to be effective in practice ${ }^{11}$.

\section{Concluding remarks}

Establishment of home rule in Iceland (1904), technical innovations introduced after the two world wars and declaration of full sovereignty (1944) slowly brought the modern times to a backward, underdeveloped and poor society. The Danish king had generated income from the Icelandic colony by auctioning rights to trade and by taxes on imports and exports. Local government was small and financed by discretionary taxes paid by the moneyed and largely used to fund placement of disabled that were not supported by their family. A changing and growing economy commanded governmental action in areas other than support of disabled. Transport infrastructure had to be erected from scratch, a university had to be established

11 In 2008, the Supreme Court of Iceland provided the Public Prosecutor with a search warrant to get documents from the Directorate of Tax Investigation (DTI) in order to investigate the reasons why the DTI did not follow the prescribed procedure (Karlsson (2014)).
(1911), an administrative system had to be adapted to new challenges. Tax policy and taxation were guided by need for funds, not by principles of efficiency or equity

As need for funds increased special interest groups used lobbying and other avenues of influence through the political system to shape the tax system to serve their own ends. Hence, corruption related to the structure and development of the Icelandic tax-system has encouraged tax evasion and tax avoidance.

Decisions and policies related to tax policy reveal a lack of political will to form the tax system in such a way that it benefits the society at large rather than serving mainly special interests. Importantly, the problem of tax system choice is not simply a technical or computational one but is rather a question of mediating among the interests of economic actors in society. Special interest groups transmit the policy preferences of their constituents-or clientele-to elected officials, while political parties are focused on maximizing their representation in forums of formal power (Parliaments, local governments, agencies). The incentives for both politicians and special interest groups are to increase their income and power either by increasing spending and controlling resources, or else by relying on specific institutional details of budgeting, taxation and legislation. Unofficially, but de facto, there is a 
direct link between political parties and special interest groups.

Tax evasion and tax avoidance affects society in many ways. First of all, it diminishes public revenue. The consequences of this are less equality, reduced government services, unbalanced public finance, decreased foreign investments and higher taxes for those who do not evade taxation.

Tax evasion belongs to the Non-Observed Economy, and measuring the size of the NOE in general, and of tax evasion in particular, is difficult and prone to error. We compared the results of applying three methods for assessing GDP (the production approach; the expenditure approach; and the income approach) and compared the results thus obtained with the documented historical facts available (verdicts, government figures and reports, OEEC, IMF, OECD), economic growth (the greater the growth, the greater the tax evasion) and with attention to the structure of the tax system. According to these, our evaluation of the magnitude of tax evasion is as follows (Table 9):

Table 9: Summary of indications for tax evation in relation to total tax revenue and GDP in Iceland from 1930 to 2008.

\begin{tabular}{ccc}
\hline Periods & $\begin{array}{c}\text { Tax evasion as } \\
\text { percentage of Tax } \\
\text { revenue }\end{array}$ & $\begin{array}{c}\text { Tax evasion as } \\
\text { percentage of } \\
\text { GDP }\end{array}$ \\
\hline $1930-1940$ & $9-17 \%$ & $1-2 \%$ \\
$1940-1950$ & $35-45 \%$ & $6-8 \%$ \\
$1950-1960$ & $20-25 \%$ & $5-7 \%$ \\
$1960-1970$ & $20-30 \%$ & $6-9 \%$ \\
$1970-1980$ & $20-25 \%$ & $7-8 \%$ \\
$1980-2000$ & $10-15 \%$ & $4-6 \%$ \\
$2000-2008$ & $15-25 \%$ & $7-11 \%$ \\
\hline
\end{tabular}

Prior to the 1970s, most of the tax evasion in Iceland was related to the falsification of records (import, export, sales tax). The administration was very weak and did not avail itself of any common rules of accounting until 1965, nor of any rules of fiscal and budgeting policy. In the wake of the great depression of the thirties and WWII, the Allies radically changed the structures of Icelandic society in general and of public finance in particular. In the late 1990s, it was the government's policy to abandon all tax controls, privatize and deregulate the major banks, and set up a tax haven in Iceland. This plan turned out to be the root of the Icelandic financial and bank crisis of 2008. During that period, tax evasion reached a historical peak, rising to more than 11 per cent of GDP per year.

\section{References}

Alpingi. (1986). Skýrsla fjármálarádherra um störf nefndar sem kannaði umfang skattsvika, sbr. ályktun Alpingis 3. maí 1984. Reykjavík: Alpingi.

Alpingi. (2005). Skýrsla starfshóps um umfang skattsvika á Íslandi. (Lögð fyrir Alpingi af fjármálarádherra á 131. löggjafarpingi 20042005.) (Vol. 2015). Reykjavík: Alpingi.

Albýðublaðið. (1995, 1 February). Kolkrabbinn stýrir 54 fyrirtækjum, Alpýdublaðid. Retrieved from http://timarit.is/view_page_init. jsp?issld $=246428$

Atvinnumálaráðuneytið. (1931). Skýrslur um nokkrar framkvæmdir ríkisins 1927-1930. Reykjavík: Atvinnumálaráduneytið.

Bjarnason, B. (1943). Samningarnir um vinstri stjórn. Hvers vegna vildi Framsókn ekki róttæka umbótastjórn? Greinargerd Sósíalistaflokksins ásamt skjölum og skilríkjum varðandi samningana. Reykjavík: Fræðslunefnd Sósílistaflokksins.

Blöndal, G. (1965). The Development of Public Expenditure in Relation to National Income in Iceland. (PhD), London School of Economcs and Political Science, London.

Blöndal, G. (1983). Balancing the Budget: Budgeting Practices and Fiscal Policy Issuus in Iceland. Public Budgeting \& Finance, 3(2), 47-63.

Borgarskjalasafn Reykjavíkur. (1940). Jón Sveinsson, vegna umsóknar um skattstjórastöдu 3. október 1940. Bjarni Benediktsson. Einkaskjalasafn nr. 360, (2-8). Borgarskjalasafn Reykjavíkur, Reykjavík.

Boukalas, P. (2015, 3 March). The Greek tax drama, http://www. ekathimerini.com. Retrieved from http://www.ekathimerini.com/ 4dcgi/_w_articles_wsite3_1_03/03/2015_547811

Brunell, T. L. (2005). The Relationship Between Political Parties and Interest Groups: Explaining Patterns of PAC Contributions to Candidates for Congress. Political Research Quarterly, 58(4), 681688.

Central Bank of Iceland (2004). Financial stability MONETARY BULLETIN (Vol. 1). Reykjavík: CBI.

Clark, E. H. (1951). An Investment Program for Iceland. Wasington D.C.: International Bank for Reconstruction and Development.

Diamond, P. A., \& Mirrlees, J. A. (1971a). Optimal Taxation and Public Production I: Production efficiency. American Economic Review, 61(1), 8-27.

Diamond, P. A., \& Mirrlees, J. A. (1971b). Optimal Taxation and Public Production II: Tax rule. American Economic Review, 61(3), 261-278.

DV. (2012, 10 February). Ólafur afsaladi sér húsi til Framsóknar, DV. Retrieved from http://www.dv.is/frettir/2012/2/10/olafurafsaladi-ser-husi-til-framsoknarflokksins/

Financial Times. (2013). Tax evasion prosecutions double in a year as Revenue cracks down. Financial Times.

Fjármálaráduneyti. 1993. Umfang skattsvikaog tillögur um aðgerðir gegn peim. Reykjavík: Fjármálaráduneyti.

Fjármálaráduneyti. (2015). Skilagrein starfshóps um gerð griðarreglna og úttekt á úrræðum skattyfirvalda til að sporna gegna skattsvikum.

Friðriksson, F. P. (1995, 10 February). Valdið, Vikublaðið. Retrieved from http://timarit.is/files/11398997.pdf-navpanes=1\&view=FitH

Government. (2010). Stjórnsýlsuskóli Stjórnarrádsins hefur göngu sína. Reykjavík: Forsætisráduneyti Retrieved from http://www. forsaetisraduneyti.is/frettir/nr/4394. 
GRECO. (2013). Group of States Against Corruption, 2013, from http: //www.greco.coe.int.

Guðmundsson, H. (2004). Halldór Laxness - ævisaga. Reykjavík: JPL útgáfa.

Gunnarsson, G. (1988). Viðreisnarstjórnin, hugmyndir og veruleiki. Ný saga, 2(1), 96-99.

Hjartarson, H. (2010). Leki úr rannsöknarskýrslu - Draumalandið. Retrieved from https://dagskammtur.wordpress.com/ 2010/03/18/leki-ur-rannsoknarskyrslu-draumalandid/

Hrdr 115. (1970).

IMF. (1972). Skýrsla um skattamál á Íslandi. Reykjavík: Fjármálaráduneyti.

IMF. (2012). Toward a New Organic Budget Law (F. A. Department, Trans.) (pp. 83). Wasington DC: International Monetary Fund.

Johnsen, G. (2014). Bringing Down the Banking System. Lesson from Iceland. New York: Palgrave macmillan.

Karlsson, J. H. (2010). Skatteftirlit í addraganda hrunsins: skattsvik í boði hverra? Stjórnmál og stjórnsýsla. Veftímarit, 1. tbl(6. árg.), 37-56.

Karlsson, J. H. (2014). Moulding the Icelandic Tax System. PrimaryIndustry-Based Special Interest Groups, Taxation, Tax Expenditure, Direct and Indirect State Support, and the Shaping of Tax Rules. (MS Economics), University of Iceland, Reykjavík. Retrieved from http://skemman.is/handle/1946/19766.

Kukkonen, M. (2008). General Legal Report Yearbook for Nordic Tax Research 2008 (pp. 13-20). Copenhagen: DJÖF Publishing Copenhagen.

NORAD, N. A. f. D. C.-o. (2009). Anti-Corruption Approaches: A Literature Review, from http://www.norad.no/en/tools-andpublications/publications/publication?key $=119213$.

OECD. (2012). International Drivers of Corruption: A Tool for Analysis, from http://www.oecd-ilibrary.org/development/internationaldrivers-of-corruption_9789264167513-en.

OEEC. (1958). Skýrsla um athugun á skattlagningu íslenzkra fyrirtækja. Reykjavík: OEEC.

PAS. (1950). A Suggested Program of Improvements in The Organization of the Goverment of Iceland. Washington D.C.: Public Administration Service.

Ragnarsson, K. (1999). Landssamband iślenskra ut́vegsmanna 60 aŕa. Útvegurinn. Fréttabréf Landssambands íslenskra útvegsmanna, 1(8), 3-5.

Ríkisendurskoðun. (2009). Endurskoðun ríkisreiknings 2008. Reykjvavík.

Smith, A. (1998 [1776]). An Inquiry into the Nature and Causes og the Wealth of Nations (Edited with an Introduction and Notes by: Kathryn Sutherland ed.). Oxford: Oxford Universty Press.
Special Investigation Commission. (2010a). Report of the Special Investigation Commission. In Alpingi (Ed.), (Vol. 1). Reykjavík: Alpingi.

Special Investigation Commission. (2010b). Report of the Special Investigation Commission. In Alpingi (Ed.), (Vol. 2). Reykjavík: Alpingi.

Statistics Iceland. (2007). Rádstöfunartekjur heimilsgeirans Hagtíðindi (Vol. 5). Reykjavík: Hagstofa Íslands.

Stiglitz, J. E. (2000). Economics of the Public Sector (3 ed.). New York: W.W. Norton \& Company.

Thorhallsson, B. (2008). The influence of ideology on the European policy of the Independence Party. In Á. Jóhannesson \& H. Björnsdóttir (Eds.), Rannsóknir í félagsvísindum (Vol. IX). Reykjavík: Félagsvísindasvið Háskóla Îslands.

Thorhallsson, B. (2010). The corporatist model and its value in understanding small european states in the neo- liberal world of the twenty-first century: the case of iceland. European Political science, 9(3), 375-386.

Thorhallsson, B., \& Kattel, R. (2012). Neo-Liberal Small States and Economic Crisis: Lessons for Democratic Corporatism. Journal of Baltic Studies, 1-21.

Tómasson, G. (2009, 20 January). Atlaga ad almannahag, Fréttablaðið. Retrieved from http://www.visir.is/atlaga-adalmannahag/article/2009836095019

Tómasson, G. (2013). Rússnesk mafia: Fann Ísland og keypti landið? Retrieved from http://blog.pressan.is/gunnart/2013/07/ 04/russnesk-mafia-fann-island-og-keypti-landid/

UN. (1993). System of National Accounts System $1993 \mathrm{Re}$ trieved March 15, 2015, from http://unstats.un.org/unsd/ nationalaccount/docs/1993sna.pdf.

University of Iceland. (2010). Blessad stríðid - Ísland í síðari heimsstyrjöldinni - Sýning Retrieved March 15, 2015, from https: //soguslodir.hi.is/?p=649).

Valdimarsson, V.U. (1984). Alpýzuflokkurinn og stjórn hinna vinnandi stétta 1934-1938. Ritsafn Sagnfræðistofnunar 12 (Vol. 12). Reykjavík: Sagnfræðistofnun.

Porláksson, J. H. (2008). Eignarhald aíślenskum fyrirtækjum. Hvert rennur hagnaður peirra og skattar? Retrieved from https://indridith.files.wordpress.com/2015/02/eignarhaldc3a1-c3adslenskum-fyrirtc3a6kjum.pdf

Wikipedia. (2015a). Lagarde List, 2015, from http://en.wikipedia.org/ wiki/Lagarde_list.

Wikipedia. (2015b). Sís Retrieved 14 July, 2015, from https://is.wikipedia.org/wiki/Samband_\%C3\%ADslenskra_ samvinnufélaga. 